\title{
REPROCESSING RERTR SILICIDE FUELS
}

by

George C. Rodrigues and

Anthony P. Gouge

Approved by:

H. D. Harmon

Research Manage $r$

Actinide Technology

Published: May 1983

\section{DISCLAIMER}

This report was prepared as an account of work sponsored by an agency of the United States Government. Neither the United States Government nor any agency thereof, nor any of their employees, makes any warranty, express or implied, or assumes any legal liability or responsibility for the accuracy, completeness, or usefulness of any information, apparatus, product, or process ofsclosed, or represents that its use would not infringe privately owned rights. Reference herein to any specific commercial product, process, or service by trade name, trademark, manufacturer, or otherwise does not necessarily constitute or imply its endorsement, recommendation, or favoring by the United States Government or any agency thereof. The views and opinions of authors expressed herein do not necessarily state or reflect those of the United States Government or any agency thereof. 


\section{DISCLAIMER}

This report was prepared as an account of work sponsored by an agency of the United States Government. Neither the United States Government nor any agency Thereof, nor any of their employees, makes any warranty, express or implied, or assumes any legal liability or responsibility for the accuracy, completeness, or usefulness of any information, apparatus, product, or process disclosed, or represents that its use would not infringe privately owned rights. Reference herein to any specific commercial product, process, or service by trade name, trademark, manufacturer, or otherwise does not necessarily constitute or imply its endorsement, recommendation, or favoring by the United States Government or any agency thereof. The views and opinions of authors expressed herein do not necessarily state or reflect those of the United States Government or any agency thereof. 


\section{DISCLAIMER}

Portions of this document may be illegible in electronic image products. Images are produced from the best available original document. 
DP-1657

\section{ABSTRACT}

The Reduced Enrichment Research and Test Reactor Program is one element of the United States Government's nonproliferation effort. High density, low enrichment aluminum-clad uranium silicide fuels may be substituted for the highly enriched aluminum-clad alloy fuels now in use. Savannah River Laboratory has performed studies which demonstrate reprocessability of spent RERTR silicide fuels at Savannah River Plant. Results of dissolution and feed preparation tests and solvent extraction processing demonstrations with both unirradiated and irradiated uranium silicide fuels are presented. 


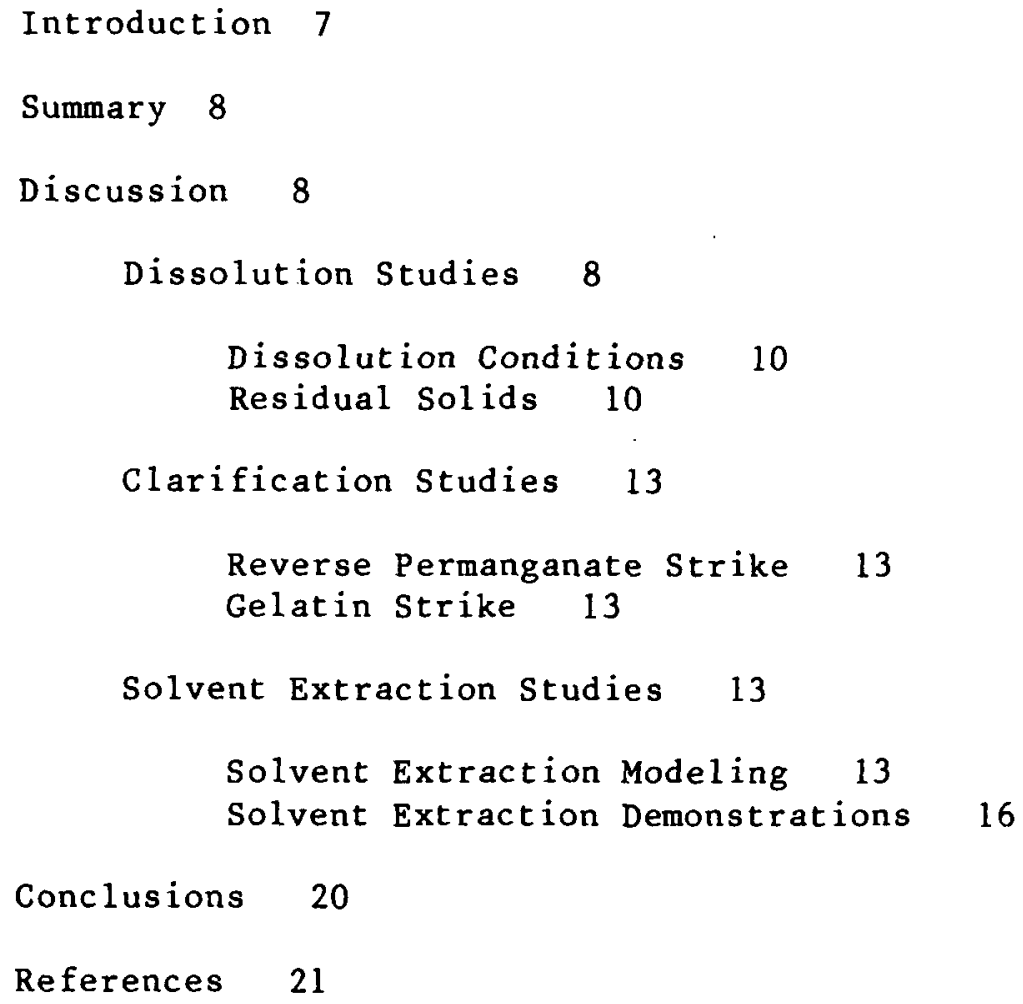




\section{INTRODUCTION}

Highly enriched uranium (HEU) fuels from a number of foreign and domestic research and test reactors are currently reprocessed at Savannah River $\mathrm{Plant}$ (SRP). Most of these reactors are being considered for conversion to low enriched uranium (LEU) fuel under the efforts of the Reduced Enrichment Research and Test Reactor (RERTR) program.1 As part of the nonproliferation effort, the RERTR program is sponsored by the United States Department of State and Department of Energy and is administered by Argonne National Laboratory (ANL). Its objective is to convert research and test reactor cores worldwide to LEU ( $20 \%{ }^{235} \mathrm{U}$ maximum) where possible in order to minimize the potential for diverting HEU to nonpeaceful uses. Ideally, this conversion should be accomplished without changing the fuel configuration or degrading reactor performance. Conversion to LEU under these constraints requires that the new fuel elements contain up to 4-1/2 times as much total uranium. Advanced powder metallurgy fabrication techniques utilizing high density oxides, aluminides, and silicides should produce reliable fuels with uranium loadings in the desired range. Candidate silicide intermetallic compounds are $\mathrm{U}_{3} \mathrm{Si}, \mathrm{U}_{3} \mathrm{Si}_{2}$, and $\mathrm{U}_{3} \mathrm{SiAl}$.

While a good deal is known about reprocessing oxides and aluminides ${ }^{2}, 3$, information on reprocessing silicides is limited and dissolution of some uranium silicides has proven difficult. ${ }^{4}$ Excessive dissolved silicon can disrupt solvent extraction. ${ }^{3,5}$ In addition, the increased uranium loading will affect actinide partitioning conditions during reprocessing. Therefore, reprocessing studies with silicide fuels were necessary to demonstrate compatability with current SRP operations.

Studies at Savannah River Laboratory (SRL) examined the operational and nuclear safety aspects of dissolution, clarification, and solvent extraction reprocessing of RERTR silicide fuels. 


\section{SUMMARY}

RERTR silicide fuels can be reprocessed at SRP. Studies with both unirradiated and irradiated fuel demonstrated dissolution, clarification, and solvent extraction steps.

RERTR silicide fuels were successfully dissolved in mercury catalyzed nitric acid in bench-scale tests. The dispersed fuel phase dissolved at least as fast as the aluminum matrix and cladding. Solids remaining after dissolution were amorphous silica containing negligible uranium. A gelatin strike ensured that dissolved silicon was reduced to levels which cause no interference with solvent extraction. Unirradiated and irradiated fuels were dissolved and clarified as feed for bench-scale solvent extraction studies.

Continuous bench-scale solvent extraction of both unirradiated and irradiated RERTR silicide fuels was demonstrated. Solvent extraction operations for processing dissolved RERTR fuel in present SRP H-Area equipment was modeled using the SEPHIS-MOD4 computer code. ${ }^{6}$ Dissolved, unirradiated $\mathrm{U}_{3} \mathrm{Si}, \mathrm{U}_{3} \mathrm{Si}_{2}$, and $\mathrm{U}_{3} \mathrm{SiAl}$ and irradiated $\mathrm{U}_{3} \mathrm{Si}$ and $\mathrm{U}_{3} \mathrm{SiAl}$ fuel were studied in miniature mixer-settler experiments, each of approximately 16 hours duration. No hydraulic disruptions were observed during these studies. Measured compositions of end streams and stage samples agreed with values predicted by the computer model.

\section{DISCUSSION}

Dissolution, clarification, and solvent extraction studies were conducted at SRL with both unirradiated and irradiated RERTR miniplates (see Figure 1) provided by ANL. These fuel elements were originally prepared for fabrication and irradiation studies. Depleted miniplates were produced during fabrication and uranium loading studies at ANL. Enriched miniplates were produced at ANL and irradiated to $\sim 30 \% 235 \mathrm{U}$ burnup in the 0 ak Ridge Research Reactor (ORR) for post-irradiation examination studies at ANL.

\section{Dissolution Studies}

Bench-scale studies demonstrated that RERTR silicide fuels show no significant difference in dissolution from aluminum clad fuels now reprocessed at SRP. Dissolution procedures for RERTR silicide fuels are based on current SRP practices and previous SRL studies on dissolution of aluminum clad fuels. $2,7-11$ 

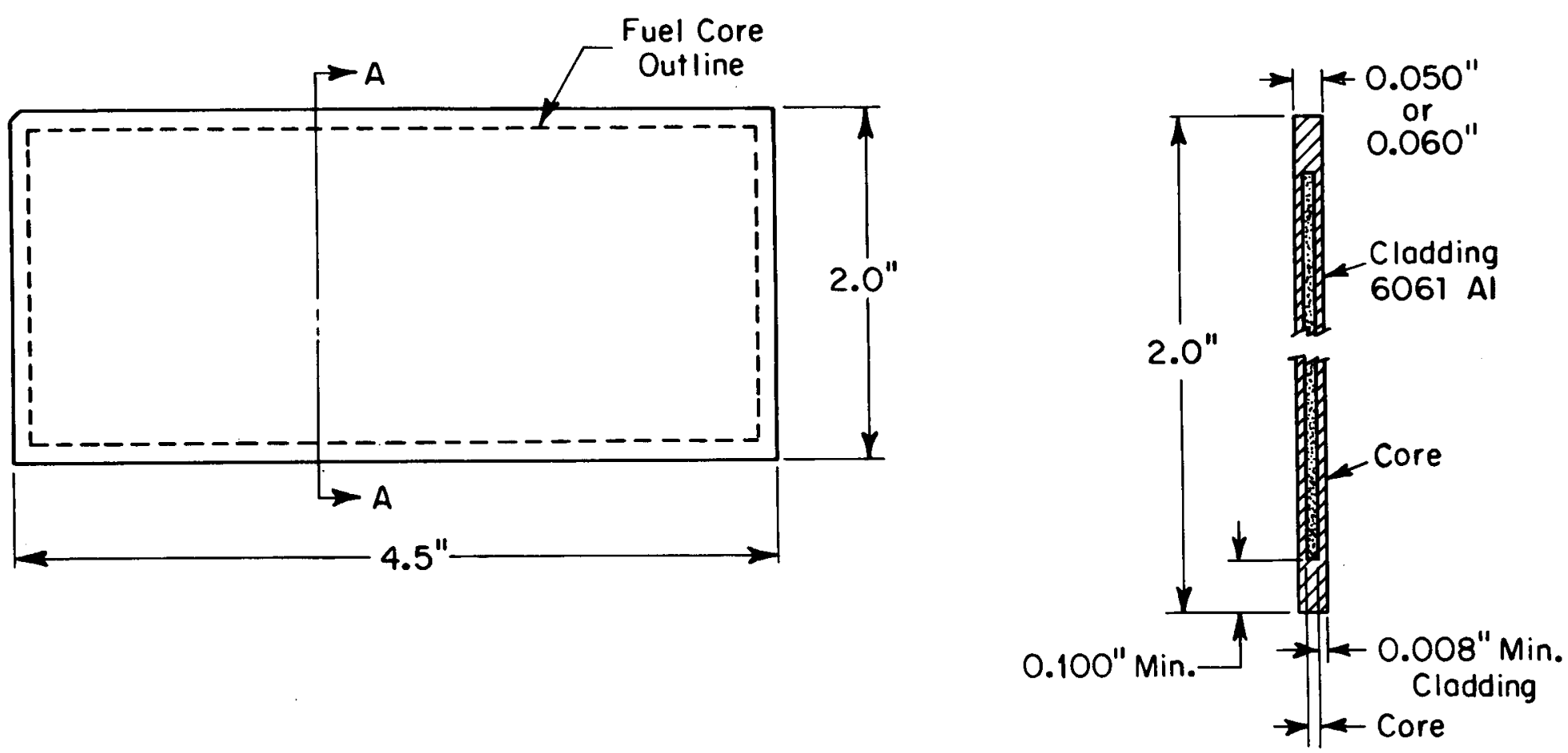

Section A-A

(Not to Scole)

FIGURE 1. RERTR Miniplate 
RERTR dissolution studies were conducted in bench-scale glassware. The dissolver apparatus consisted of an electrically heated flask fitted with a water cooled reflux condenser. The flask was also fitted with a burette for metering in reagents during dissolution. Studies with the intensely radioactive irradiated fuel were conducted in SRL's heavily shielded High Level Cells (HLC) facility. Average composition of the unclarified dissolver solutions is shown in Table 1 .

The acid consumed during the course of a dissolution was replenished periodically with $15.6 \mathrm{M} \mathrm{HNO}_{3}$. A two-hour boiling digestion period dissolved any fueT particles remaining after all large cladding fragments were dissolved. This digestion also precipitated most of the dissolved silicon as fluffy, white amorphous silica.

Dissolution Conditions. Boiling $3 \mathrm{M} \mathrm{HNO}_{3}-0.002 \mathrm{M} \mathrm{Hg}^{+2}$ completely dissolved sections of unirradiated miniplates of all three silicide compositions. This dissolving recipe produced vigorous initial dissolution without uncontrollable foaming and gave an average dissolution time of 7.0 hours. Irradiated $U_{3} \mathrm{Si}$ and $U_{3} \mathrm{SiAl}$ fuels dissolved easily in an average of 6.8 and 8.4 hours, respectively, with this recipe. The dispersed fuel particles dissolved as fast or faster than the aluminum matrix and cladding in all tests, which is a necessary condition to ensure that no unsafe accumulation of fissile solids will occur in plant operations. The addition of $0.01 \mathrm{M} \mathrm{F}^{-}$did not affect the dissolution time of either unirradiated or irradiated fuel. The range of total dissolution times (Table 2). of 6-12 hours for all tests compares favorably with times for fuels now processed at SRP.

A number of dissolutions were made with reduced $(0.0002 \mathrm{M}) \mathrm{Hg}^{+2}$. This change increased the average dissolution time of unirradiated fuel by $50 \%$ to 10.6 hours, but would result in a tenfold decrease in mercury to high level waste storage. The average dissolving time for irradiated $U_{3} S i$ fuel increased by $44 \%$, but did not change significant $1 y$ for irradiated $U_{3}$ SiAl fuel. Increasing the nitric acid concentration ( $8 \mathrm{M} \mathrm{HNO}_{3}-0.002 \mathrm{M} \mathrm{Hg}$ ) did not significant ly affect the overall dissolution time of unirradiated $\mathrm{U}_{3} \mathrm{SiAl}$ fuel. However, the initial dissolution rate was so high that foaming was barely controlled in the oversized condenser used.

Residual Solids. Solids remaining after dissolution contained negligible uranium (Table 3 ). These solids appeared to be amorphous silica. X-ray diffraction analysis of unirradiated fuel residues showed no crystal structure. Neutron activation analysis of these solids detected negligible uranium. The solids from irradiated fuel were darker and more granular in appearance, but 


\section{TABLE 1}

Average Composition of Unclarified Dissolver Solutions

\begin{tabular}{l}
$\begin{array}{l}\text { Type } \\
\text { Fue 1 }\end{array}$ \\
\hline
\end{tabular}$\frac{\mathrm{U}}{(\mathrm{gm} / \mathrm{L})} \frac{\mathrm{H}^{+}}{(\mathrm{M})} \frac{\mathrm{Al}^{+3}}{(\mathrm{M})} \frac{\begin{array}{l}\text { Dissolved } \\
(\mathrm{mg} / \mathrm{L})\end{array} \frac{\mathrm{NO}_{3}^{-}}{(\mathrm{M})}}{}$

Unirradiated

$\begin{array}{llllll}\mathrm{U}_{3} \mathrm{SiAl} & 21.7 & 3.8 & 1.1 & 40 & 7.3 \\ \mathrm{U}_{3} \mathrm{Si} & 25.1 & 3.2 & 1.0 & 77 & 6.1 \\ \mathrm{U}_{3} \mathrm{Si}_{2} & 19.7 & 3.3 & 1.2 & 69 & 6.6\end{array}$

Irradiated

$\begin{array}{lllllr}\mathrm{U}_{3} \mathrm{SiAl} & 17.8 & 4.7 & 1.1 & * & 10.0 \\ \mathrm{U}_{3} \mathrm{Si} & 16.6 & 4.0 & 1.4 & * & 9.4\end{array}$

* Not analyzed 
TABLE 2

Effect of Dissolution Conditions on Dissolving Time

Type
Fuel $\quad \frac{\mathrm{Hg}^{+2}}{(\mathrm{M})} \quad \frac{\mathrm{F}^{-}}{(\mathrm{M})} \frac{\begin{array}{c}\text { Dissolving } \\ \text { Time }\end{array}}{\text { (hrs) }}$

Unirradiated

$\begin{array}{llll}\mathrm{U}_{3} \mathrm{SiAl} & 0.002 & 0 & 9.2 \\ & 0.0002 & 0 & 11.8 \\ & 0.002 & 0.01 & 10.3 \\ & & & \\ \mathrm{U}_{3} \mathrm{Si} & 0.002 & 0 & 5.9 \\ & 0.0002 & 0 & 10.2 \\ \mathrm{U}_{3} \mathrm{Si}_{2} & 0.002 & 0 & 6.0 \\ & 0.0002 & 0 & 9.7\end{array}$

Irradiated

$\begin{array}{llll}\mathrm{U}_{3} \mathrm{SiAl} & 0.002 & 0 & 8.6 \\ & 0.002 & 0.01 & 8.2 \\ & 0.0002 & 0.06 & 8.2 \\ \mathrm{U}_{3} \mathrm{Si} & 0.002 & 0 & 7.1 \\ & 0.002 & 0.01 & 6.6 \\ & 0.0002 & 0 & 9.8 \\ & 0.0002 & 0.06 & 11.2\end{array}$

TABLE 3

Oranium Loss in Dissolution

Composition \% U Lost

Unirradiated

$\begin{array}{ll}\mathrm{U}_{3} \mathrm{SiAl} & 0.28 \% \\ \mathrm{U}_{3} \mathrm{Si} & 0.08 \% \\ \mathrm{U}_{3} \mathrm{Si}_{2} & 0.17 \%\end{array}$

Irradiated

$$
\mathrm{U}_{3} \mathrm{Si} \quad 0.01 \%
$$


again appeared to be precipitated silica. Plasma torch spectroscopy showed negligible uranium in these solids also, along with a high, but undetermined level of silicon.

\section{Clarification studies}

Current SRP clarification steps were successfully tested on dissolved unirradiated and irradiated RERTR silicide fuels.

Reverse Permanganate Strike. The dissolved fuel was first treated with a reverse permanganate strike. Digested dissolver solution was brought to $75^{\circ} \mathrm{C}$ and $0.014 \mathrm{M} \mathrm{Mn}\left(\mathrm{NO}_{3}\right)_{2}$ added followed by sufficient $\mathrm{KMnO}_{4}$ to react with $90 \%$ of the $\mathrm{Mn}^{+2}$ present by:

$$
\mathrm{Mn}\left(\mathrm{NO}_{3}\right)_{2}+2 \mathrm{KMnO}_{4}+2 \mathrm{H}_{2} \mathrm{O} \rightarrow 5 \mathrm{MnO}_{2}++2 \mathrm{KNO}_{3}+4 \mathrm{HNO}_{3}
$$

The precipitated $\mathrm{MnO}_{2}$ cake centrifuged easily from the solution in less than five minutes at $1100 \mathrm{G}^{\prime} \mathrm{s}$ in a bottle centrifuge.

Gelatin Strike. A gelatin strike may be desirable even though the digestion successfully removed dissolved silicon for most of the runs to levels which should not interfere with solvent extraction $(<100 \mathrm{ppm}) .50 \mathrm{mg} / \mathrm{L}$ of gelatin was added to selected dissolver solutions and held at $75^{\circ} \mathrm{C}$ for 30 minutes. Dissolved silicon was reduced to less than $70 \mathrm{ppm}$ following sequential reverse permanganate and gelatin strikes. The gelatin-polymerized silica easily centrifuged from the solution in less than 10 minutes at $1100 \mathrm{G}^{\prime} \mathrm{s}$ in a bottle centrifuge.

Threefold excess permanganate was present following the reverse permanganate strike for several runs. Even under these conditions, the dissolved silicon content dropped to $70 \mathrm{ppm}$ or below (average $40 \mathrm{ppm}$ ) following the gelatin strike.

\section{Solvent Extraction Studies}

A solvent extraction flowsheet appropriate for processing RERTR silicide fuels at SRP was developed and successfully demonstrated with both unirradiated and irradiated actual fuels.

Solvent Extraction Modeling. In order to ensure that solvent extraction reprocessing of RERTR silicide fuels is compatible with SRP capabilities and standards, ${ }^{2}$ the first cycle and the second uranium cycle (Figures 2 and 3 ) for modified Purex solvent extraction were modeled and optimized using the SEPHIS-MOD4 computer $\operatorname{code}^{6}$. This program accurately predicts endstream and stage 


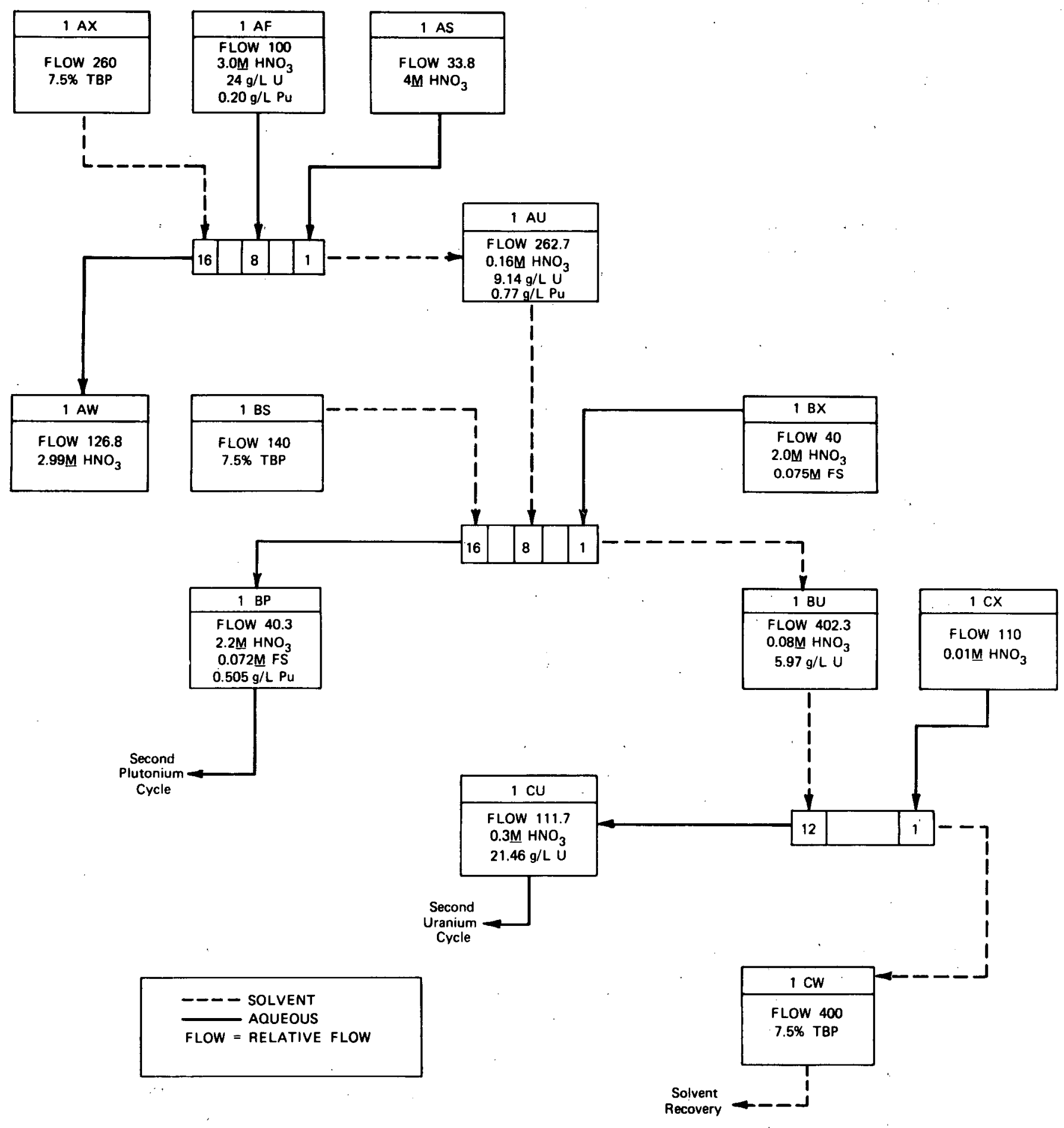

FIGURE 2. RERTR First Solvent Extraction Cycle 


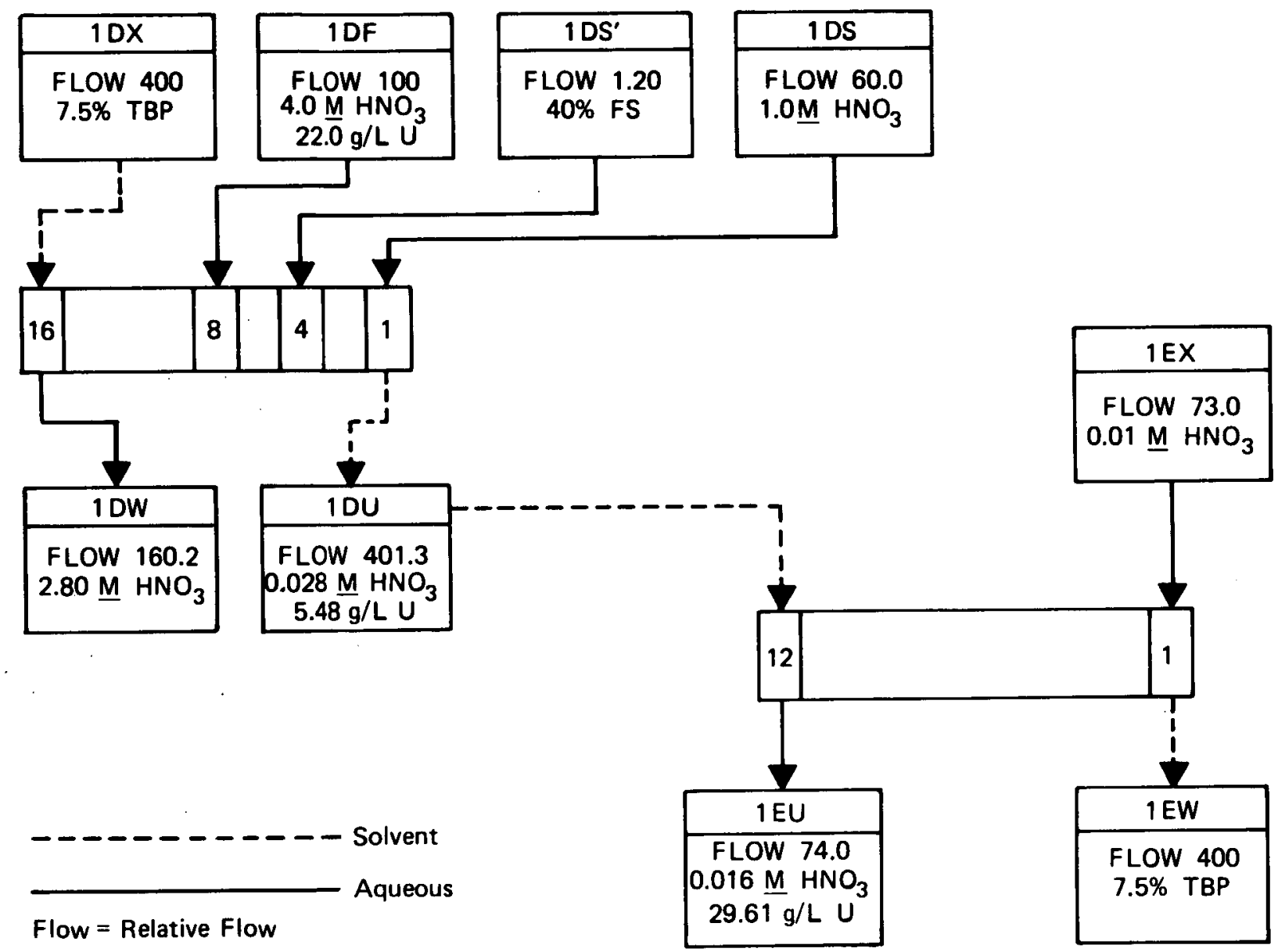

FIGURE 3. RERTR Second Uranium Decontamination Cycle 
compositions, as we 11 as stage inventories, for variable input stream flows and concentrations and equipment configurations. Established SRP technical limits, which are designed to ensure that hydraulic and nuclear safety limits are not exceeded, were imposed on the model.

The first cycle was optimized on the basis of minimum product losses ( $\mathrm{U}$ and $\mathrm{Pu}$ ) and the maximum uranium throughput. The second uranium cycle was optimized on the bas is of minimum evaporation costs. The second plutonium cycle was not studied, as the present SRP flowsheet for plutonium will adequately process the plutonium recovered from RERTR fuels.

Solvent Extraction Demonstrations. The first cycle A and B bank flowsheet developed using the SEPHIS-MOD4 model was successfully demonstrated in 1:10,000 scale miniature mixer-settlers (nominal feed rate - $30 \mathrm{~mL} / \mathrm{hr}$ ) in the shielded SRL intermediate level cell facility with actual clarified unirradiated and irradiated RERTR silicide fuel solutions. These tests demonstrated that the additional silicon dissolved with RERTR silicide fuels would not cause hydraulic disruption in solvent extraction. As this problem occurs primarily in the first cycle $A$ and $B$ banks, only these banks were studied. Runs were 16 to 18 hours in length, which by past experience is long enough to establish that plant mixer-settlers will operate satisfactorily without hydraulic disruption. The miniature mixer-settler banks were brought to uranium, aluminum, and nitric acid equilibrium by running with a synthetic depleted uranium feed for 4 to 5 hours prior to introducing actual dissolved fuel to the banks.

First cycle solvent extraction operated satisfactorily with dissolved and clarified solutions of each of the unirradiated RERTR silicide fuel compositions. No phase separation or hydraulic problems were observed during these runs which might indicate excessive dissolved silicon. Measured uranium and nitric acid concentrations agreed with values predicted by the SEPHIS-MOD4 computer model. Uranium and nitric acid concentration profiles in both phases were plotted for the first cycle from stage samples removed from the banks after one run and compared with profiles generated by the model (Figures 4 and 5 ). Uranium and nitric acid concentrations in the end streams were also measured and matched values predicted by the mode1 (Table 4). The measured uranium concentrations did deviate from the computer model predictions at low uranium levels, a known limitation of the SEPHIS codel 2 which is not significant for this application. Uranium losses to both the first cycle aqueous waste ( $1 \mathrm{AW}$ ) and first cycle plutonium product stream (1BP) also are shown in Table 5. The losses to both of these streams are we 11 below $0.01 \%$ and indicate excellent recovery of the uranium. The calculated uranium cross-contamination in the hypothetical plutonium product averaged $1200 \mathrm{ppm}$. 


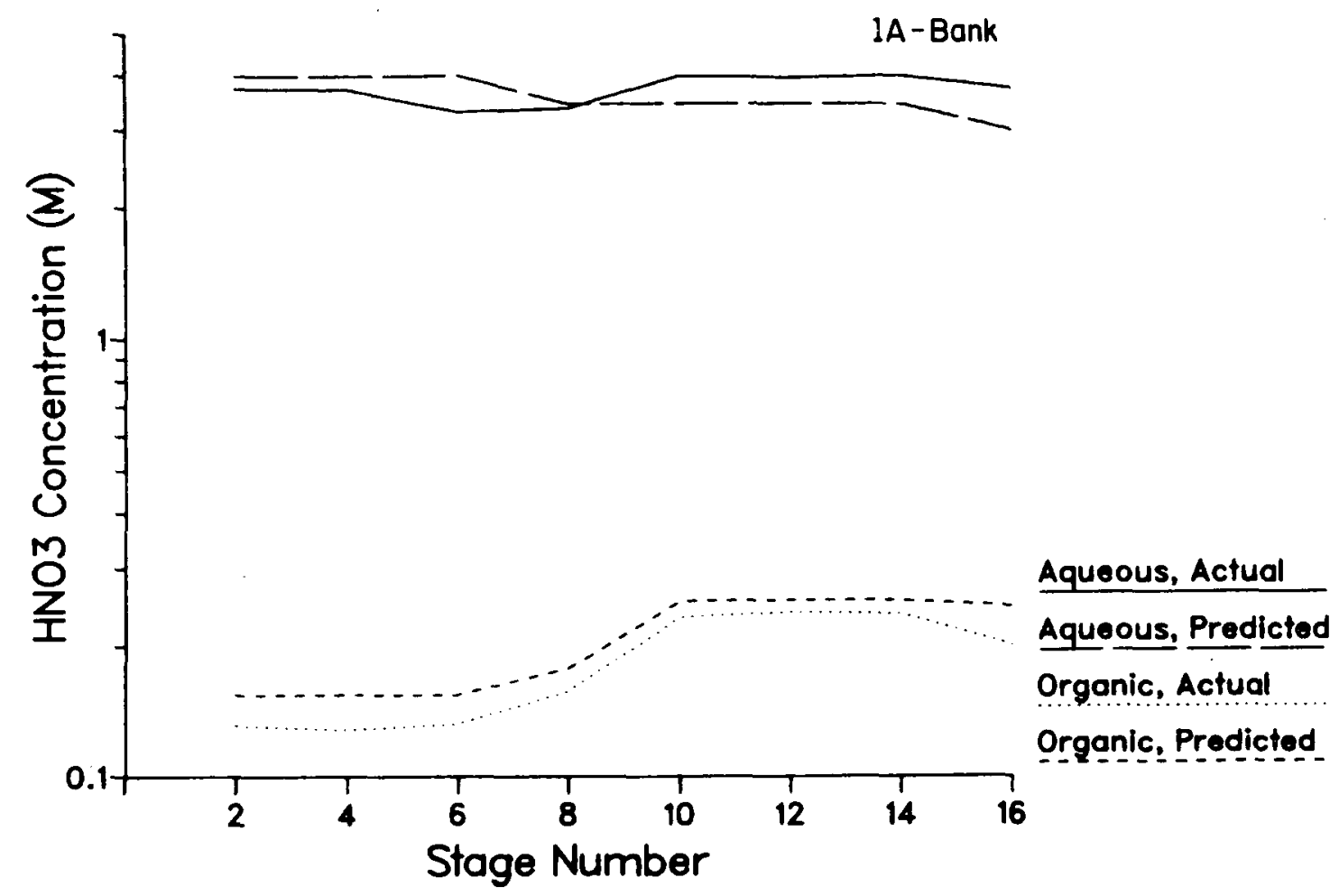

FIGURE 4. Measured vs. Predicted Acid Concentrations 


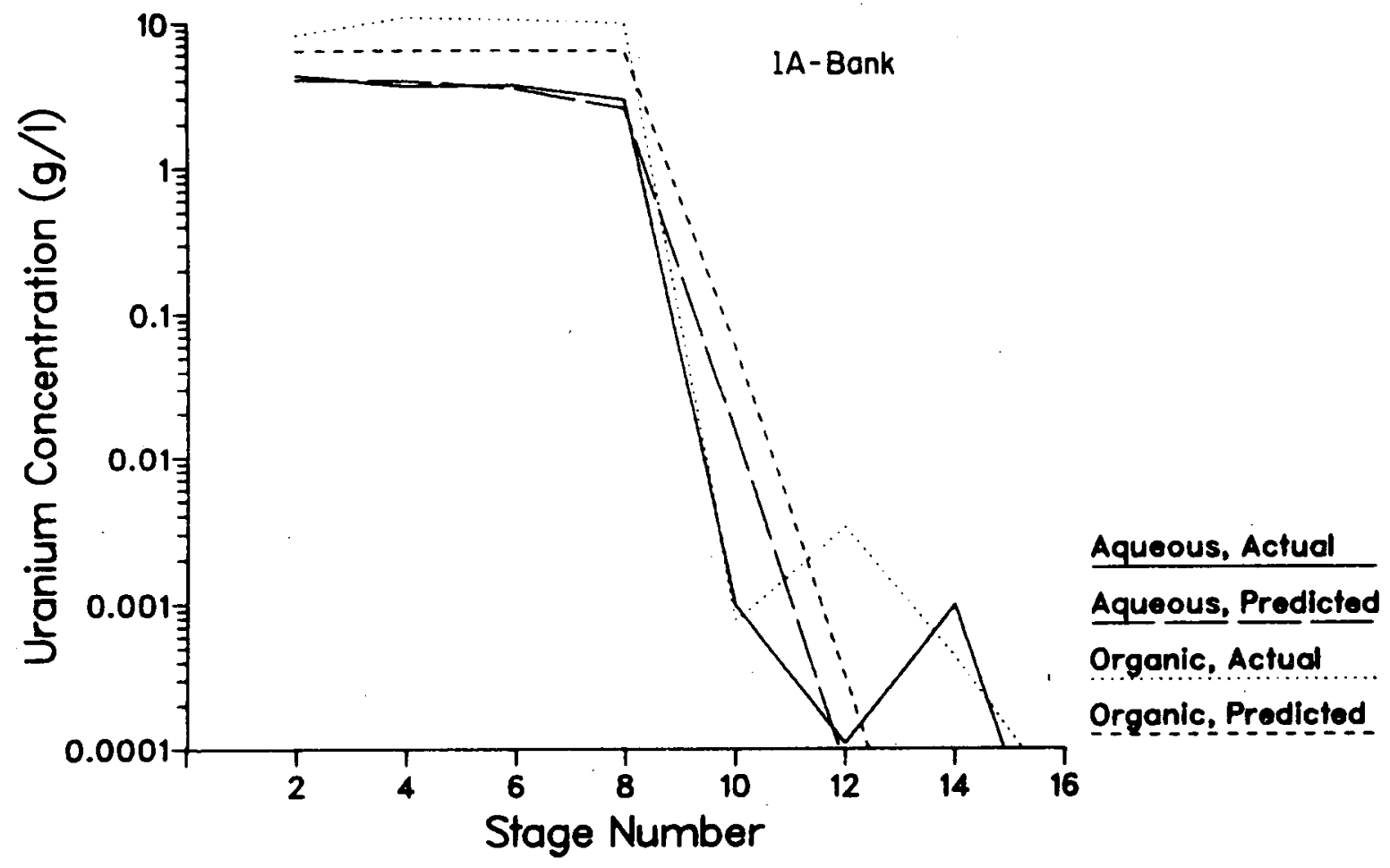

FIGURE 5. Measured vs. Predicted Uranium Concentrations 
TABLE 4

Comparison of Measured and Predicted End Stream Compositions*

\begin{tabular}{|c|c|c|c|c|}
\hline Stream & $\begin{array}{l}\text { Me asured } \\
\mathrm{U}\end{array}$ & $\begin{array}{l}\text { SEPHIS } \\
\text { Calculated } \\
\text { U }\end{array}$ & $\begin{array}{l}\text { Me asured } \\
\mathrm{H}^{+}\end{array}$ & $\begin{array}{l}\text { SEPHIS } \\
\text { Calculated } \\
\mathrm{H}^{+}\end{array}$ \\
\hline & $(\mathrm{gm} / \mathrm{L})$ & $(\mathrm{gm} / \mathrm{L})$ & $(\mathrm{M})$ & $(M)$ \\
\hline
\end{tabular}

$\begin{array}{lllll}\text { 1BU } & 7.25 & 7.67 & 0.078 & 0.158\end{array}$

$1 \mathrm{BP} \quad 6.45 \times 10^{-4} \quad 2.24 \times 10^{-9} \quad 2.42 \quad 2.21$

IAW $\quad 2.1 \times 10^{-6} \quad 1.9 \times 10^{-4} \quad 3.32 \quad 2.99$

* Unirradiated fue 1

TABLE 5

Average Uranium Losses

Fuel Condition $\quad$ Stream $\quad \frac{U \text { Loss }}{(\%)}$

$\begin{array}{lll}\text { Unirradiated } & \text { IAW } & 1.4 \times 10^{-3} \\ & 1 \mathrm{BP} & 1.2 \times 10^{-3}\end{array}$

Irradiated $\quad 1 \mathrm{AW} \quad 7.62 \times 10^{-4}$

$1 \mathrm{BP} \quad 1.3 \times 10^{-3}$ 
During the last few hours of one run with unirradiated fuel, a zone of slow coalescence formed at the aqueous/organic interface of the settler section of the feed stage. However, complete phase separation was observed, and no disruption of the operation resulted. There was no significant difference in the dissolved silicon level from previous runs.

Two solvent extraction runs with irradiated RERTR silicide fuel demonstrated that the first cycle solvent extraction flowsheet successfully separates fission product activity (Table 6 ) and is not affected by any radiation induced chemical changes in the dissolved fuel and solvent. During one run, a zone of slow coalescence formed between the aqueous and organic phases in the settler of each stage in the 1A bank extraction section after about 2 hours of operation. However, this condition improved as the run progressed, and hydraulic operation of the banks was not disrupted. Analytical results showed that this phenomenon, which is common in irradiated solvent extraction experiments, did not affect the chemical operation of the mixer-settler banks.

TABLE 6

Fission Product Decontamination in Solvent Extraction*

Stream Average Decontamination Factor

\begin{tabular}{|c|c|c|c|c|}
\hline & $\beta-\gamma$ & $95 \mathrm{Zr}$ & ${ }^{95} \mathrm{Nb}$ & $1 \longdiv { 4 4 } \mathrm { Ce }$ \\
\hline $1 \mathrm{BP}$ & $2.84 \times 10^{4}$ & $3.17 \times 10^{4}$ & $1.75 \times 10^{7}$ & $7.68 \times 10^{5}$ \\
\hline $1 \mathrm{BU}$ & $2.35 \times 10^{4}$ & $2.81 \times 10^{2}$ & $4.31 \times 10^{4}$ & $1.02 \times 10^{5}$ \\
\hline
\end{tabular}

\section{CONCLUSIONS}

These studies demonstrated that spent RERTR silicide fuels can be successfully reprocessed at SRP. Head end dissolving and feed preparation rates are compatible with currently projected campaign schedules. Because the dispersed fuel phase dissolved at least as fast as the aluminum matrix, no nuclear safety problems are anticipated. Trace fluoride is probably not necessary to reliably dissolve these fuels. A gelatin strike is recommended to ensure solvent extraction operability.

The solvent extraction flowsheet developed for RERTR silicide fuels is within present technical and nuclear safety guidelines and performed as predicted. No hydraulic disruption of solvent extraction is expected while reprocessing RERTR silicide fuels. 


\section{REFERENCES}

1. A. Trave11i, R. A. Lewis, J. E. Matos, E. Delaney, W. Ballard, and L. Akers, "U.S. Reduced-Enrichment Research and Test Reactor Program," Trans. Am. Nuc. Soc., Vol. 30, pp 725-726 (November 1978).

2. M. L. Hyder, W. C. Perkins, M. C. Thompson, G. A. Burney, E. R. Russe11, H. P. Holcomb, and L. F. Landon, Processing of Irradiated, Enriched Uranium Fuels at the Savannah River Plant, USDOE Report DP-1500, E. I. du Pont de Nemours and Co., Savannah River Laboratory, Aiken, SC (April 1979).

3. B. E. Paige, G. W. Gibson, and K. L. Rhode, The Effect of Silicon on Fabrication and Reprocessing of Aluminum Alloy Reactor Fuels, USDOE Report IN-1194, Idaho Nuclear Corporation, National Reactor Testing Station, Idaho Falls, ID (November 1968).

4. J. J. Katz and E. Rabinowitz, The Chemistry of Uranium (First Edition), Part 1, p. 228, McGraw-Hill Book Company, New York (1951).

5. H. J. Groh, Removal of Silica from Solutions of Nuclear Fuels, USAEC Report DP-293, E. I. du Pont de Nemours and Co., Savannah River Laboratory, Aiken, SC (June 1958).

6. A. D. Mitche11, SEPHIS-MOD4: A User's Manual to a Revised Model of the Purex Solvent Extraction System, USDOE Report ORNL-5471, Union Carbide Corporation, Oak Ridge National Laboratory, Oak Ridge, TN 37370 (May 1979).

7. D. L. Foster, J. E. Savolainen, and R. G. Wymer, "Nuclear Reactor Fuel Dissolution," Proc. Internatl. Conf. Peaceful Uses Atomic Energy, Vo1. 9, PP 546-550 (1956).

8. R. G. Wymer and R. E. Blanco, "Uranium-Aluminum Alloy Dissolution," Industrial and Engineering Chemistry, Vol. 59 (1), (January 1957).

9. W. C. Perkins, Dissolution of Pu-Al Alloy. USAEC Report DP-702, E. I. du Pont de Nemours and Co., Savannah River Laboratory, Aiken, SC (March 1962). 
10. W. C. Perkins, Dissolution of Highly Irradiated Pu-U Alloy, USAEC Report DP-874, E. I. du Pont de Nemours and Co., Savannah River Laboratory, Aiken, SC (February 1964).

11. W. C. Perkins, Dissolving Uranium Oxide-Aluminum Fuel, USAEC Report DP-1337, E. I. du Pont de Nemours and Co., Savannah River Laboratory, Aiken, SC (November 1973).

12. A. D. Mitchel1, A Comparison Between SEPHIS-MOD4 and Previous Models of the Purex Solvent Extraction System, USDOE Report ORNL/TM-6565, Union Carbide Corporation, Oak Ridge National Laboratory, Oak Ridge, TN 37830 (February 1979). 